This article has been published in a revised form in Journal of Southeast Asian Studies, 47 (3). pp. 333-340. https://doi.org/10.1017/S0022463416000229

This version is published under a Creative Commons CC-BY-NC-ND. No commercial re-distribution or re-use allowed. Derivative works cannot be distributed. (C) The National University of Singapore 2016

\title{
Introduction: Transitions from late prehistory to early historic periods in Mainland \\ Southeast Asia, c. early to mid-first millennium CE
}

Stephen A. Murphy and Miriam T. Stark

Studies of early Southeast Asia focus largely on its 'classical states', when rulers and their entourages from Sukhothai and Ayutthaya (Thailand), Angkor (Cambodia), Bagan (Myanmar), Champa and Dai Viet (Vietnam) clashed, conquered, and intermarried one another over an approximately six-century-long quest for legitimacy and political control. Scholarship on Southeast Asia has long held that such transformations were largely a response to outside intervention and external events, or at least that these occurred in interaction with a broader world system in which Southeast Asians played key roles. ${ }^{1}$ As research gathered pace on the prehistory of the region over the past five decades or so, it has become increasingly clear that indigenous Southeast Asian cultures grew in sophistication and complexity over the Iron Age in particular. This has led archaeologists to propose much greater agency in regards to the selective

Stephen A. Murray is Curator (Southeast Asia), Asian Civilisations Museum, Singapore. Miriam T. Stark is Professor, Department of Anthropology, University of Hawai'i at Manoa.

Correspondence in connection with this article should be addressed to: stepheninasia@hotmail.com; miriams@hawaii.edu.

${ }^{1}$ See reviews in Craig Reynolds, 'A new look at old Southeast Asia', Journal of Asian Studies 54, 2 (1995): 419-46; Victor Lieberman, Strange parallels: Southeast Asia in global context, c.800-1830, vol. 1: Integration on the mainland (Cambridge: Cambridge University Press, 2003). 
adaptation of incoming Indic beliefs and practices than was previously assumed under early scholarship of the nineteenth and early to mid-twentieth century. ${ }^{2}$

More than thirty years ago, Karl Hutterer emphasised the role of archaeology as key to understanding early Southeast Asia. ${ }^{3}$ Archaeological and art historical research in the last two decades now suggests a more complex and nuanced Mainland Southeast Asian landscape during the early to mid-first millennium $\mathrm{CE} .{ }^{4}$ Scholars have used material culture to track internal development and interaction at regional and transregional scales. ${ }^{5}$ We now maintain that early to

\footnotetext{
${ }^{2}$ See for example, George Coedès, The Indianized states of Southeast Asia, ed. Walter F. Vella, trans. Susan B. Cowing (Honolulu: East-West Center Press, 1968).

${ }^{3}$ Karl Hutterer, 'Early Southeast Asia: Old wine in new skins? A review article', Journal of
} Asian Studies 41, 3 (1982): 559-70.

${ }^{4}$ Miriam Stark, 'Early Mainland Southeast Asian landscapes in the first millennium A.D.', Annual Review of Anthropology 35 (2006): 407-32.

${ }^{5}$ For example, Bérénice Bellina and Ian Glover, 'The archaeology of early contact with India and the Mediterranean world, from the fourth century BC to the fourth century AD', in Southeast Asia: From prehistory to history, ed. Ian Glover and Peter Bellwood (London: RoutledgeCurzon, 2004), pp. 68-88; Sunil Gupta, 'The Bay of Bengal interaction sphere (1000 BC-AD 500)', Bulletin of the Indo-Pacific Prehistory Association 25, 3 (2005): 21-30; Hsiao-chun Hung, Kim Dung Nguyen, Peter Bellwood and Mike T. Carson, 'Coastal connectivity: Long-term trading networks across the South China Sea', Journal of Island and Coastal Archaeology 8, 3 (2013): 384-404; Himanshu Prabha Ray, 'Multi-religious linkages across the Bay of Bengal during the first millennium CE', in Before Siam: Essays in art and archaeology, ed. Nicholas Revire and Stephen A. Murphy (Bangkok: River Books; Siam Society, 2014), pp. 134-51. 
mid-first millennium Southeast Asians engaged in a series of political and social entanglements with foreigners, and with each other. We also contend that these entanglements produced discrete, state-like polities with more similarities in aesthetics and ideology than most scholars realise.

Examining the intricate mix of statecraft, bureaucracy, and belief that forged Mainland Southeast Asia's earliest states requires interdisciplinary approaches from archaeology, art history, religious studies, and history, among others. Bringing these perspectives to bear on early to mid-first millennium CE Mainland Southeast Asia is the goal of this special issue of the Journal of Southeast Asian Studies (JSEAS). Archaeologists and art historians use newlyavailable data to reappraise the emergence of some of the region's first named polities: Dvāravatī, Funan, Zhenla, Pyu and Mon. Authors pay particular attention to dynamics involved in the transition from late prehistory to early/proto-historic periods. The pace of archaeological research on this period has accelerated recently, but the exact nature and timing of the transitions from prehistoric to early/proto-historic polities in various regions of Southeast Asia remains unclear. In which regions does the close examination of archaeological data suggest continuity from antecedent cultures into these first millennium CE polities? Can scholars interpret disjunctures in the material record and settlement as cultural discontinuities? How can archaeological and art historical evidence inform us in regard to transregional interaction between these polities? By merging archaeological, art historical and epigraphic information on the first millennium CE together, the articles in this issue offer insights on the transition to history and subsequent early state formation, the inter-polity dynamics that guided these shifts, and the ways in which disciplinary approaches constrain or shape interpretations. 
These issues challenge contributors to transcend conventional time-space systematic boundaries and to bridge disciplinary divides between art history and archaeology. We hope that our efforts to dissolve these largely artificial temporal, spatial and disciplinary boundaries produce new insights on the transregional dynamics that led to organisational shifts during the first millennium CE. For instance, the authors were asked to think beyond conventional spatial boundaries like 'Pyu', 'Dvāravatī’, 'Pre-Angkor', and 'Cham'. Michael Vickery’s analysis of Pre-Angkor Cambodia effectively argues that Chams and Khmers interacted with each other; ${ }^{6}$ more recent art historical research indicates numerous connections between Pyu, Dvāravatī, PreAngkor, and Cham. ${ }^{7}$ Epigraphic and art historical evidence indicates that first millennium CE populations interacted with, and influenced, each other; we asked our authors to identify material culture evidence of this transregional interaction.

The second challenge is to rethink connections between 'prehistoric' traditions and their immediately succeeding 'historic' traditions. In the past, a perceived break from prehistoric to historic cultures encouraged some scholars to overemphasise external influences during this period of transformation and to ignore evidence for inter-polity interaction. ${ }^{8}$ The difficulties

\footnotetext{
${ }^{6}$ Michael Vickery, Society, economics, and politics in Pre-Angkor Cambodia: The 7th-8th centuries (Tokyo: Centre for East Asian Cultural Studies for Unesco; Toyo Bunko, 1998). ${ }^{7}$ John Guy, ed., Lost kingdoms: Hindu-Buddhist sculpture of early Southeast Asia (New York: Metropolitan Museum of Art, 2014).

${ }^{8}$ Coedès, The Indianized states; Ramesh Chandra Majumdar, Ancient Indian colonisation in South-East Asia, Maharaja Sayajirao Gaekwad Honorarium Lectures, 1953-1954 (Baroda: M.S. University of Baroda Press, 1955).
} 
inherent in understanding this transition, which lie at the crux of this volume, were aptly summed up over thirty years ago by Hutterer who states that

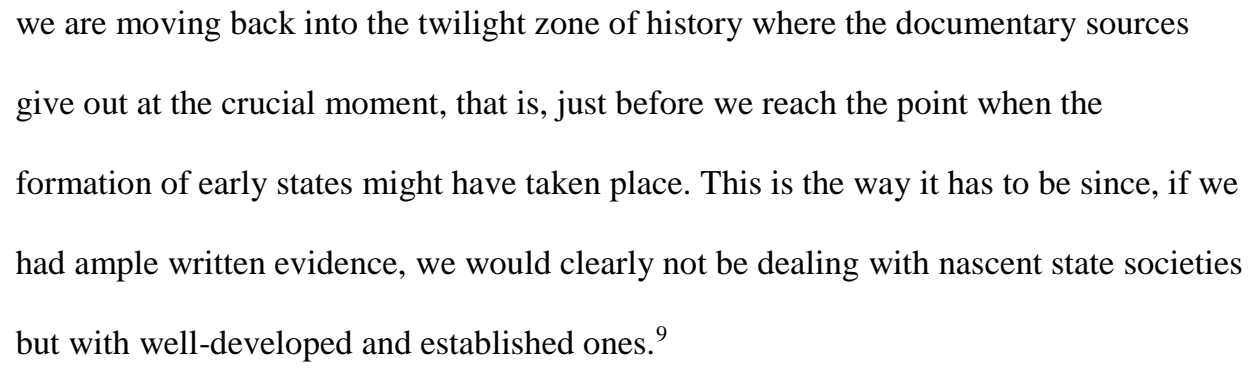

Archaeological work since the 1980s has progressed significantly and we are now in a better position, if not to answer these questions, then at least to explore them in a more detailed and thorough way. In Vietnam, for instance, a growing body of archaeological evidence suggests that Cham grew directly out of Sa Huynh in the early centuries CE; in Cambodia, Pre-Angkorian settlements emerged directly out of the 'Funan' polity that Chinese visitors described. ${ }^{10}$

In Thailand there is now ample evidence that 'Dvāravatī' grew directly out of 'Iron Age' societies before the seventh century CE. Chureekamol Onsuwan Eyre's study of hierarchical and heterarchical social systems in the eastern Chao Phraya River Valley, for instance, provided a much more close reading of the process of localisation and development of complex societies. ${ }^{11}$ Her research did not indicate the existence of site hierarchy from $200 \mathrm{BCE}$ to $300 \mathrm{CE}$. However,

\footnotetext{
${ }^{9}$ Hutterer, 'Early Southeast Asia': 562.

${ }^{10}$ William Southworth, 'The coastal states of Champa' (pp. 211-13), and Miriam Stark, 'PreAngkorian and Angkorian Cambodia' (pp. 89-119), in Glover and Bellwood, Southeast Asia from prehistory to history.

${ }^{11}$ Chureekamol Onsuwan Eyre, 'Social variation and dynamics in metal age and protohistoric central Thailand: A regional perspective', Asian Perspectives 49, 1 (2011): 43-84.
} 
by $c$. the fifth century CE there is a clear shift towards a hierarchical settlement pattern around the site of Chansen, which she sees as indicative of a two-level hierarchy and clearly indicating the formative stages of state-level society.

Following on from her work, a recently published article by Rispoli and her colleagues establishes a chronology for central Thailand. ${ }^{12}$ They emphasise that the appearance of early states such as Dvāravatī had deep roots that grew out of the prehistoric period. They propose an eight-hundred-year process of gradual social complexity emerging in central Thailand spanning the fifth century BCE to the second century CE. They argue that it accelerated over time as exposure and interaction with India intensified and the process of localisation consequently increased. In doing so they have provided one framework within which we may study the origins of these early states.

The characteristics and chronology of the Iron Age of Mainland Southeast Asia are key factors in understanding how these early states emerge. This period starts around the fifth century $\mathrm{BCE}^{13}$ and by the mid-to-late Iron Age, trade and contact with India had intensified. Sites such as Khao Sam Kaeo on the Isthmus of Kra in Thailand for instance, most likely had artisans from India located there working glass into beads. ${ }^{14}$ Were sites such as these the first

${ }^{12}$ Fiorella Rispoli, Roberto Ciarla and Vincent C. Pigott, 'Establishing the prehistoric cultural sequence for the Lopburi region, central Thailand', Journal of World Prehistory 26, 2 (2013): 101-71; Eyre ('Social variation and dynamics') identifies this localism at a regional level in central Thailand as well.

${ }^{13}$ See Higham, this vol.; and Rispoli et al., 'Establishing the prehistoric'.

${ }^{14}$ Bérénice Bellina, 'Beads, social change and interaction between India and Southeast Asia', Antiquity 77, 296 (2003): 285-97; Ian Glover and Bérénice Bellina, 'Ban Don Ta Phet and Khao 
examples of India-Southeast Asia interactions? Do they represent locations of cultural intersection and exchange that established traditions of interaction that then spread further inland over the course of the Late Iron Age? Charles Higham's article in this volume, for instance, argues for an agricultural revolution involving ploughing and permanent, probably irrigated, rice fields in the Mun River Valley of northeast Thailand by the fifth century CE. These developments, he argues, underwrote a rapid rise of social elites.

What then were the incentives for these newly formed social elites in terms of adopting and adapting incoming Indian religions? Royal patronage has often played a key role in the development and spread of Buddhism. Janice Stargardt's article in this volume traces the adoption of Buddhism on both elite and popular levels in early first millennium CE Myanmar. Incoming Buddhist monks and Brahmans possessed some powerful new tools, such as languages (Sanskrit and Pali) and a new vocabulary of art and monumental architecture. As Sheldon Pollock has demonstrated, by the fifth century Sanskrit had moved beyond being a purely sacred language and had begun to be used in the political and royal arena, primarily to eulogise leaders. ${ }^{15}$ The sangha could legitimise the royalty whose patronage they received. Thus the process becomes mutually beneficial. Nicolas Revire's article, for instance, looks at the ideology of merit and how it was utilised by elites in Dvāravatī and Zhenla.

Sam Kaeo: The earliest Indian contacts re-assessed', in Early interactions between South and Southeast Asia: Reflections on cross-cultural exchange, ed. Pierre-Yves Manguin, A. Mani and Geoff Wade (Singapore: ISEAS; New Delhi: Manohar, 2011), pp. 17-46.

${ }^{15}$ Sheldon I. Pollock, The language of the gods in the world of men: Sanskrit, culture and power in premodern India (Berkeley: University of California Press, 2009), pp. 123-5. 
Along with these earthly concerns, leaders who adopted Buddhism or Brahmanism could also now claim higher moral and ethical status, self-styling themselves as bodhisattvas or dhammarajas (a king who rules in accordance with the teachings of the Buddha). The ability of the sangha to declare that a king was a chakravartin (an idealised universal Buddhist monarch) or dhammaraja would be a powerful tool in the hands of an astute Buddhist monk. In terms of Buddhism, it appears that over time, reciprocal arrangements developed between royalty, the lay community, and the sangha which further strengthened the bond between them. Monumental architecture allowed elites to simultaneously demonstrate both their munificence and their power while the new artistic modes provided a complex set of iconography which they could also utilise.

This overlaying of new incoming gods onto pre-existing local cults can be illustrated by the process that occurred at Wat Phu, in Champasak province, southern Laos. As a result of contact with incoming Brahmanic belief systems, a mountain overlooking the sanctuary began to be worshipped as a natural linga and subsequently became known as a Lingaparvata. Śiva, in his earliest manifestations in Southeast Asia, often appeared as a linga. It seems that prior to the arrival of Śaivism, an indigenous religion was present at Wat Phu focused on worship of the mountain's spirit named Podouli. ${ }^{16}$ The close association between Śiva as a god of the mountain and the linga, a symbol of the god's fertilising energy, made it readily adaptable to local cults. This also had political associations too. A number of examples erected by the ruler Citrasena in the Dangrek (Dang Raek) Range of northeast Thailand for instance show that linga were

\footnotetext{
${ }^{16}$ Kamaleswar Battacharya, 'The religions of ancient Cambodia', in Sculpture of Angkor and ancient Cambodia: Millennium of glory, ed. Helen I. Jessup and Thierry Zéphir (Washington, D.C.: National Gallery of Art, 1997), pp. 36-9.
} 
associated with the conquest of territory. ${ }^{17}$ Using Śaivism to unify local deities, rulers could therefore exert religious and political control over newly acquired territories.

The articles in this volume move geographically across the region from west to east, beginning in Myanmar and ending in Cambodia. Janice Stargardt's article, 'From the Iron Age to early cities at Sri Ksetra and Beikthano, Myanmar', provides new archaeological evidence for transitions from prehistory in the late first millennium BCE to proto-urban and fully urban development at Sri Ksetra and Beikthano in the first millennium CE. Early developments in the technologies of water control, iron production, brick architecture, and ceramics meant this society was well-placed to incorporate and adapt incoming Indic religious (Buddhism and Brahmanism) and political ideas. Stargardt draws a clear picture of the transitional period within Sri Ksetra and Beikthano, dispelling early Indianisation theories and reappraising the nature and timing of contact between the Pyu and various regions within India.

Moving eastward into central Thailand, Stephen Murphy's article, 'The case for protoDvāravatī: A review of the art historic and archaeological evidence', problematises the overly rigid divisions and periodisation of Thai archaeology, particularly in regard to the late prehistoric and early historic period. Building on Andrew Barram and Ian Glover's argument that the Dvāravatī period has earlier antecedents than the traditional date of the sixth century, ${ }^{18}$ he

${ }^{17}$ Paul Lavy, 'As in heaven, so on earth: The politics of Viṣnu, Śiva and Harihara images in preangkorian Khmer civilisation', Journal of Southeast Asian Studies 34, 1 (2003): 26-7; see also Revire, this vol.

${ }^{18}$ Andrew Barram and Ian Glover, 'Re-thinking Dvaravati', in From Homo erectus to the living traditions: Choice of papers from the 11th International Conference of the European Association 
illustrates how the fourth to fifth centuries in particular provide sufficient evidence to indicate a proto-Dvāravatī period. It is within this timespan that the nascent traits and characteristics of what will become Dvāravatī culture are developing. In doing so, his work brings the timing of the transition from late prehistory to early history more in line with developments taking place throughout Southeast Asia.

Nicolas Revire's article, 'Dvāravatī and Zhenla in the seventh-eighth centuries: A transregional ritual complex', challenges the overly strict division of Buddhism and Brahmanism during first-millennium Thailand and Cambodia. Specifically, he calls into question the understanding that Dvāravatī is synonymous with Buddhism and Zhenla with Brahmanism. He shows that Brahmanism was present at key Dvāravatī sites such as U Thong and Nakhon Pathom. The presence of a linga at the former, for instance, may indicate that the ruler was to some extent identifying himself with the god Śiva, while also actively patronising Buddhism. Likewise, Buddhism was present to a certain extent in Zhenla. By reappraising the material culture and inscriptions of these two regions his article emphasises a more hybrid nature of the religions through the lens of the ideology of merit.

The next two articles move us into northeast Thailand, the region that has seen the most extensive archaeological research into Southeast Asian prehistory since Wilhelm Solheim launched his Mekong Valley Salvage Project in 1963-64. ${ }^{19}$ Charles Higham's article, ‘State formation in the Mun Valley', tackles the transition from the Late Iron Age to the early historic

of Southeast Asian Archaeologists, ed. Jean-Pierre Pautreau et al. (Chiang Mai: Silkworm, 2008), pp. 175-82.

${ }^{19}$ Chester F. Gorman and Wilhelm G. Solheim II, ‘Archaeological salvage program:

Northeastern Thailand — first season', Journal of the Siam Society 54, 2 (1966): 111-81. 
period by focusing on the Mun Valley. Based on many years of archaeological research in the region, he endeavours to illustrate that by the Late Iron Age, communities had became more hierarchical in societal organisation. This resulted from the introduction of technologies such as iron, which in turn has a major impact on agriculture and warfare. The exploitation and control of salt resources may also have been a factor in this increased stratification of society. He posits that these local leaders may have in turn become the poñ so often referred to in Pre-Angkorian inscriptions. His article strives to reconcile archaeological, art historical and epigraphic evidence for this key transitional period in the northeast of Thailand.

Caitlin Evans, Nigel Chang, and Naho Shimizu's article, 'Sites, survey, and ceramics: Settlement patterns of the first to ninth centuries CE within the Upper Mun River Valley, northeast Thailand', provides somewhat of a counterpoint to Higham's article. By again focusing on the Mun River Valley, their research suggests that the region did not sustain large-scale, unified polities like those developing in central Thailand (Dvāravatī) and Cambodia (Zhenla). It serves as a reminder that regional variation exists throughout Mainland Southeast Asia and cautions us not to over-generalise our understandings of the Iron Age. For instance, they illustrate that while settlements grew and consolidated in the Late Iron Age, little evidence exists for settlement pattern reorganisation to support the kind of multi-tiered sociopolitical organisation using Indic models of statecraft. They further argue that lay communities continued to maintain their long-term settlement and structure, with a local village or kinship focus, well into the historic period. The overall picture presented by their research is of a region that, while transitioning into historic timeframes, retains many of its traditional practices and ways of life. The region's population embraced Buddhism and Brahmanism by about the sixth to seventh 
centuries, but did not unify under a particular polity until the ninth to tenth centuries (when the Angkorian state incorporated this region as part of its northwestward expansion).

In contrast to the abundance of prehistoric archaeological research in northeast Thailand over the past five decades, much less attention has been given to this period in neighbouring Cambodia. Several factors explain this imbalance, from geopolitical history to research priorities: most Cambodia-focused archaeologists have prioritised the historic Angkorian period. Dougald O’Reilly and Louise Shewan's article, 'Phum Lovea: A moated precursor to the Pura of Cambodia?', is therefore a welcome addition to scholarship on early Cambodia. Their excavations at Phum Lovea, an Iron Age site located in the Greater Angkor area, illustrates many of the elements characteristic of the transition from late prehistory to early history, including increasing sociopolitical complexity, intensified inter- and trans-regional mercantile activity, differential access to resources, social conflict, technological transfer, and developments in site morphology. While the authors' acknowledge that this site may be on the fringes of later developments in state-level Angkor, Phum Lovea does provide one of the only examples to date of an excavated Iron Age site in this area.

Moving northwards, Piphal Heng's article, 'Transition to the Pre-Angkorian period: A regional perspective from Thala Borivat', looks at similar developments in the region of Thala Borivat, a Pre-Angkorian settlement on the banks of the Mekong just south of the Laotian border in Cambodia. Like Higham, Heng too correlates archaeological and epigraphic evidence in regard to the Pre-Angkorian elites, particularly the poñ and mratan. His research also indicates that small scale proto-historic settlements began to become incorporated into large ones during the fourth to seventh centuries, the latter then becoming major Pre-Angkorian centres. 
Ian Glover, one of the few archaeologists who have engaged with this period and these issues throughout his career, concludes the volume with some reflections on the issues and difficulties of linking the prehistoric and early historic periods. Establishing robust chronological sequences is one of our greatest obstacles, and he reviews the state of archaeological research throughout Mainland Southeast Asia. Integrating archaeological, art historical and epigraphic evidence into coherent scenarios presents additional challenges, which several articles in this volume address in a variety of ways. Glover highlights the third to sixth centuries CE in particular as a period of 'convergence' where local Southeast Asian societies integrated influences from South Asia, which over time resulted in them forming their own discrete identities. Moving forward, Glover calls for more systematic excavations of early historic sites and greater attention to developing fuller and more accurate absolute chronologies of the first millennium CE.

Several common strands wend their way through the articles in this special issue of JSEAS, which address the transitional period from diverse geographic and disciplinary perspectives. Early first millennium CE proto-historic societies, all of which had the hallmarks of stratified societies, emerged from the 'Iron Age' predecessors of the last centuries BCE and early centuries CE. As Glover points out in his concluding remarks, these Mainland Southeast Asian communities actively engaged in trade networks that linked polities within and beyond Southeast Asia, into the Bay of Bengal and South China Sea respectively, by the third through sixth centuries CE. Stargardt outlines key developments at Sri Ksetra during the phase; Murphy argues for a proto-Dvāravatī period in the fourth to fifth centuries; Higham documents social stratification in the Mun River Valley at this time; and both Higham and Heng argue that the poñ of later Pre-Angkorian inscriptions descended from Late Iron Age elites. These processes reflect 
a complex mix of indigenous and exogenous inspiration whose uniquely Southeast Asian expressions lack direct prototypes in source areas beyond the region.

This special issue's authors fill critical disciplinary and temporal gaps in our knowledge of Mainland Southeast Asia's earliest historical period to move discussions of Early Southeast Asia forward. Recently acquired archaeological, epigraphic, and art historical research all enrich our understandings of changes associated with early state formation in the region. Our work is not yet done; several of our authors, in fact, offer preliminary findings from their ongoing, longterm research projects. Yet this collective work illustrates that organisational changes associated with 'Early South East Asia' ${ }^{20}$ grew out of robust local patterns of emergent stratification and developed from intra- and inter-regional interaction networks.

It is hoped that the essays in this volume will be of value not only to archaeologists and art historians but also to the wider field of historical research. During the timespan discussed herein, many of the cultures were in the process of transitioning from pre-literate to literate societies and represent the forerunners of the great historic societies of the region. A greater understanding of the processes that led to these changes should in turn allow for a clearer picture of how the characteristics of states such as Angkor, Bagan, Champa, Dai Viet, Sukhothai and Ayutthaya emerged.

${ }^{20}$ Following Ralph B. Smith and William Watson, eds., Early South East Asia: Essays in archaeology, history and historical geography (New York: Oxford University Press, 1979). 